Karadeniz Uluslararası Bilimsel Dergi

Volume: 46, Summer-2020, p. (235-256)

ISSN: 1308-6200 DOI: https://doi.org/10.17498/kdeniz.684398

Research Article

Received: February 4, 2020 | Accepted: May 6, 2020

This article was checked by intihal.net.

\title{
SİNOPE BATI NEKROPOLÜNDEN YENİ BİR GÖMÜ ALANI - ORD 2016
}

\section{A NEW BURIAL GROUND FROM THE WESTERN NECROPOLIS OF SINOPE - ORD 2016}

\section{НОВЫЙ МОГИЛЬНИК ИЗ ЗАПАДНОГО НЕКРОПОЛЯ В СИНОПЕ - ORD 2016}

\section{Eray AKSOY*}

\section{ÖZ}

Arkeolojik sondaj çalışmaları, antik Karadeniz'in önemli liman kentlerinden biri olan Sinop'un (antik Sinope) arkeolojik potasiyelinin anlaşılması adın büyük önem arz etmektedir. Bu kazılardan biri olan "ORD 2016" kente ulaşımı sağlayan boğazın güney kısmında olacak şekilde Gelincik Mahallesi olarak bilinen bölgede gerçekleştirilmiştir. Bir inşat yapılması düşünülen tek bir parselde gerçekleştirilen kazıda birden fazla sayıda açma açılmış ve bu açmalar dâhilinde arkeolojik buluntulara, mimari unsurlara ve bazı mezarlara ulaşılmıştır.

Bu çalışma ORD 2016 kapsamında açığa çıkarılan arkeolojik buluntuların, mimari unsurların ama en çok da mezarların irdelenmesi üzerine odaklanacaktır. Çalışma kapsamında ilk olarak kazının gerçekleştirildiği alanın antik kent ve çevresi bağlamındaki konumu ve önemi aktarılmıştır. Buluntu konumları ve sıralamalarının daha iyi anlaşılabilmesi adına kazı süreci de kısa ancak yeterli derecede detay verecek șekilde paylaşılmıștır. Hem bu aşamada hem de mezarların değerlendirmesi esnasında özellikle eserler üzerinde durularak gömü alanı ile mezarların tarihlemesi de gerçekleștirilmiştir.

Çalışmalar sonucunda ORD 2016 kapsamında kazısı gerçekleştirilen alanın Sinope'nin Güney Nekropolü'nün küçük bir bölümünü teşkil ettiği anlaşılmıştır. Mezarlar ve sundukları buluntu repertuvarları ise tüm gömülerin sıradan kişilere ait olduğunu göstermektedir. Mezarlar civarında açığa çıkarılmış olan Dor sütunu biçimli ve yazıtlı bir mezar belirteci ise bölgedeki mezarlarda bu tipte yer belirticilerin tercih edilmiş olabileceğine işaret etmektedir. Mezarlar ışığında Erken Hellenistik - Erken Roma arasına tarihlenebilen bu gömü alanının kullanımını kazılarda ele geçen başka buluntular ışığında Klasik Dönem'e kadar çekmek mümkün olmuștur.

Anahtar Kelimeler: Sinope, nekropol, Hellenistik, Roma, bodur lekythos, Dor biçimli mezar belirteci.

\footnotetext{
* ORCID: 0000-0002-6201-5529. Arkeolog, Sinop Arkeoloji Müzesi, erayaksoy3@hotmail.com.
} 


\title{
Sinope Batı Nekropolünden Yeni Bir Gömü Alanı - Ord 2016
}

\begin{abstract}
Archaeological Test Excavations play an important role for the understanding of the archaeological potential of Sinop (ancient Sinope) which was one of the most important port cities of ancient Black Sea. One of these excavations, named as "ORD 2016", took place within the Gelincik District of the city which is situated at the southern portion of the isthmus. The excavations conducted in multiple openings within a parcel that was chosen for a building construction yielded a varia of archaeological artefacts, architectural elements and some tombs.

This paper will focus mainly on the evaluation of the tombs revealed within ORD 2016 together with other archaeological artefacts and architectural elements. First, the overall location and the importance of the locality where the excavation took place will be revealed. Then, a short but descriptive telling of the excavation process will be shared for a better understanding of the find locations and their arrangements. A special attention will be paid to the finds as they will be mediums of dating for the tombs and the whole area as well.

The evaluations have shown that the parcel excavated within the scope of ORD 2016 must have belonged to a burial ground from the Southern Necropolis of Sinope. The tombs together with their finds abled us to state that this burial ground only received tombs of ordinary people. An inscribed miniature grave marker in the form of a Doric capital able us to realise that some tombs were marked with such indicators. Especially the tombs help us to date this burial ground between the Early Hellenistic and Early Roman periods whereas other fragmentary ceramics indicate to a use that can be pulled back until the Classical Period.

Keywords: Sinope, necropolis, Hellenistic, Roman, squat lekythos, miniature Doric capital shaped grave marker.
\end{abstract}

\section{АННОТАЦИЯ}

Археологические исследования играют важную роль для определения археологического потенциала города Синопа (древней Синопы), который был одним из наиболее важных древних портовых центров на побережье Черного моря. Одни из таких раскопок, получившие название «ORD 2016», проводились в городском районе Гелинчик, который расположен в южной части перешейка. Раскопки, проведенные на нескольких объектах на участке, который был выбран для строительства здания, выявили различные археологические артефакты, архитектурные элементы и несколько погребений.

В данной статье, наряду с изучением других археологических артефактов и архитектурных элементов, основное внимание будет уделено анализу погребений, обнаруженных во время проведения ORD 2016. Во-первых, будет изучено общее расположение и значение местности, где проводились раскопки. Затем, для лучшего понимания места находок и их расположения будет дано краткое, но содержательное описание процесса раскопок. Особое внимание будет уделено находкам, поскольку они станут основанием для датировки погребений и всего этого участка в целом.

Анализ показал, что участок, изученный в рамках ORD 2016, должен принадлежать могильнику из Южного некрополя в Синопе. Конструкция погребений вместе с находками в них дают возможность сделать вывод, что этот могильник предназначался только для захоронения простых людей. Находка миниатюрного надгробия в форме дорической капители с надписью позволила нам выяснить, что некоторые погребения были отмечены такими указателями. Прежде всего погребения помогают нам датировать этот могильник между ранним эллинистическим и ранним римским периодами, тогда как некоторые фрагменты керамики, найденные на исследованном 


\section{Eray AKSOY}

участке, указывают также на более раннюю жизнедеятельность, которая может восходить к классическому периоду.

Ключевые слова: Синоп, некрополь, Эллинизм, Римское время, приземистый лекиф, миниатюрное надгробие в форме дорической капители с надписью

\section{Giriş ${ }^{1}$}

Sinop (antik adıyla Sinope), bir Miletos kolonisi olmasından itibaren Karadeniz'in en önemli liman kentlerinden biri olmuş, Pontus Krallığı' na uzun yıllar başkentlik yapmış ve Karadeniz ticaretindeki rolünü antik çağın sonuna kadar da korumuştur. Kentin, antik dönemlerde sahip olduğu zenginlik ve ihtişam hakkındaki bilgilerimiz yazılı kaynaklar (Strabon, Geographika, XIX, XI:10, XII, III:11) dışında arkeolojik kazılardan da sağlanmaktadır (Kaba ve Vural 2018). Özellikle 2010'lu yıllardan itibaren kentte hızlı bir ivme kazanan inşaat ve kentsel dönüşüm çalışmaları neticesinde sıklaşan arkeolojik sondaj kazılarının kent hakkındaki bilgimize kattıkları yadsınamayacak kadar çoktur (Kaba ve Vural, 2018, s. 447-457).

Kentin Gelincik Mahallesi'nde 19 Pafta, 276 Ada, 91 Parsel'de bir inşaat sebebiyle 2016 yılında başlatılan “ORD Kazısı” da bu kazılardan bir diğeridir (Resim 1). Oldukça dar bir alan içerisinde gerçekleştirilmiş kazı çalışmaları kentin özellikle Geç Hellenistik-Erken Roma gömü alanlarının anlaşılması bakımından önemli sonuçlar doğurmuştur. Aslında ORD 2016 kapsamında gerçekleştirilen kazılar oldukça az sayıda ve tipte mezar ile nitelenmektedir. Bu durumun ardındaki sebeplerden biri açılan açmaların azlığı, diğeri ise bu az sayıdaki açmadan sadece bir tanesinde mezarlara rastlanılmış olunmasıdır. Bu bağlamda, ORD'nin tek başına bir nekropol teşkil etmekten ziyade bir nekropolün daha küçük bir bölümünü teşkil ettiği açıktır. Konumu sayesinde ORD'nin aslında Sinop'un ada kısmına ulaşımı sağlayan boğazın batısında yer alan ve "Batı Nekropol" olarak adlandırılabilecek gömü alanının bir parçası olduğu kolaylıkla söylenebilecektir (Resim 2). Bundan dolayı, ORD bünyesindeki alanı kesin şekilde bir "nekropol" olarak tanımlamaktansa tam yayılımını henüz tespit edemediğimiz batı nekropolüne ait daha küçük bir "gömü alanı” olarak kabul etmek daha doğru olacaktır. Bu yaklaşımla ele alındığında ORD gömü alanının düzenlenişi, barındırdığı mezar tipleri ve buluntularının irdelenmesi gerekliliği daha da önem teşkil etmektedir. Öyle ki nekropol çalışmaları bağlamında kentin diğer kısımlarına kıyasla neredeyse hiç araştırılmamış olan bu bölgenin genel yapısı, barındırdığ 1 mezar tipleri ve buluntularının anlaşılması büyük oranda ORD sayesinde gerçekleşecektir.

ORD’nin Sinope'nin Batı Nerkopolü için sergilediği önemin anlaşılması adına ilk başta ele alınacak konu kazı süreci olacaktır. Kazı sürecine değinirken açığa çıkarılmış olan mezarlar dışında tespit edilmiş çeşitli kalıntılar veya buluntulara da özellikle değinilecektir. Ardından açığa çıkarılmış olan mezarlar tipolojileri, gömü

${ }^{1}$ ORD 2016 kazısı boyunca desteğini benden esirgemeyen Arkeolog Hamdiye CILAZ ÇAKIROĞLU'na teşekkürlerimi sunarım. Ayrıca; bu çalışmayı gerçekleştirmemi mümkün kılan Sinop Arkeoloji Müzesi Müdürlügüne de teşekkür ederim. Fikir ve görüşleriyle çalışmam boyunca beni destekleyen Dr. Öğr. Üyesi Hazar KABA'ya ve tüm çizimleri gerçekleştiren Sinop Üniversitesi arkeoloji öğrencileri Serap YİĞİT ile Aslı KILIÇOĞLU'na da bu satırlarda teşekkür etmeyi bir borç bilirim. 


\section{Sinope Batı Nekropolünden Yeni Bir Gömü Alanı - Ord 2016}

şekilleri ve buluntuları bağlamında incelenecektir. En sonda ise alanın bütünleşik bir şekilde anlamlandırılması adına farklı başlıklar altında incelenmiş olan konular bir arada ele alınıp yorumlanacaktır.

\section{ORD 2016 Kazısı Ve Buluntuları}

ORD 2016 Kazısı antik kente ulaşımı sağlayan boğazın hemen güneyinde kalan parsellerden birinde gerçekleştirilmiştir. ${ }^{2}$ Parselin etrafi pek çok site, otel ve apartman ile sıkı sıkıya çevrelenmiş olsa da topoğrafik değerlendirme ORD'nin antik dönemdeki hali hakkında çıkarımlara varmayı mümkün kılmaktadır. Bir zamanlar kente ulaşımı sağlayan antik yolun en kuzey noktasını teşkil ettiği bu nekropol alanı (Batı Nekropol) denize kadar inen çeşitli yükseltilerdeki tepelerin üzerine yayılmış olmalıydı. ORD bünyesindeki parsel de hiç kuşkusuz bu deniz kenarındaki nekropolün önemli bir parçası idi. Antik topoğrafyayı değiştiren ciddi boyutlardaki modern yapılaşma maalesef hemen hemen tüm bölgeye yayılmış durumdadır. $\mathrm{Bu}$ bağlamda, ORD ve yakın civarındaki kazılmamış parseller arkeolojik verilere ulaşmayı mümkün kılacak birkaç bakir alandan biri haline gelmektedir. Bu durum, ORD'nin bilimsel bir çerçevede ele alınma gerekliliğini artırmakta hatta çevrede yer alan ve henüz kazılmamış olan parsellerin sunacağı potansiyelin anlaşılması adına da önem arz etmektedir.

ORD 2016 kapsamında gerçekleştirilen arkeolojik çalışmaların ilk bölümü alanın kuzeybatı ve güneydoğusunda açılmış olan 5 x $5 \mathrm{~m}$. ölçülerinde iki açmada gerçekleştirilmiştir (1 ve 2 No.lu açmalar)(Resim 1 \& 3). Daha sonra bu iki açmanın tam orta kısmında $3 \times 3 \mathrm{~m}$. ebatlarında bir açma daha açılarak çalışmalara devam edilmiştir (3 No.lu Açma). Üçüncü açmanın $2 \mathrm{~m}$. doğusuna yine 3 x $3 \mathrm{~m}$ ebatlarında bir açma daha açılmıştır (4 No.lu Açma). Özellikle, parselin güneydoğusunda kalan 4. No.lu Açma'da mezarlara rastlanılması söz konusu alanın bir nekropol olabileceğini göstermiştir. Bunun üzerine olası diğer mezarlara daha bütüncül bir çerçevede ulaşma adına parselin güney kısmı tamamen kazılmıştır.

İlk açılan açma olan "1 No.lu Açma" parselin kuzeybatı kısmında kalmaktadır. 5 x 5 m. ebatlarındaki bu açmada henüz çalışmaların başında $0,50 \mathrm{~m}$. derinlikte ana toprak seviyesine ulaşılmıştır. Yine de kazı $0,30 \mathrm{~m}$. daha devam ettirilmiş ve açma $0,80 \mathrm{~m}$. derinlikte sonlandırılmıştır. Söz konusu açmada hiçbir arkeolojik kalıntı veya buluntuya rastlanmamıştır.

ORD bünyesinde açılan bir sonraki açma olan 5 x $5 \mathrm{~m}$. m ebatlarındaki "2 No.lu Açma" parselin güneydoğusunda açılmıştır. Bu açmanın güneydoğu kesitinin 0,50 m. kuzeyinde, 0,55 m. derinlikte bir kiremit mezar açığa çıkarılmıştır (Mezar 1). Yine bu açmada $1,95 \mathrm{~m}$. derinlikte ikinci bir kiremit mezar daha ortaya çımıştır (Mezar 2). Mezar 2'nin kaldırılmasını takiben açma içerisinde devam ettirilen çalışmalarda kuzey kesitte olacak şekilde aynı seviyede 1 adet alabastron ele geçmiştir. ${ }^{3}$ Pişmiş topraktan imal edilmiş olan alabastronun daha iyi bilinen su mermerinden yapılmış benzerlerini taklit ettiği açıktır (Angermeier, 1936; Kanowski, 1983)(Resim 4:a). Eserin korunagelmiş yüksekliği $14 \mathrm{~cm}$. iken gövde

\footnotetext{
${ }^{2}$ Kazı raporu için bkz. "Sinop Müzesi 01/11/2016 tarih ve 364 Sayılı Kazı Raporu”.

${ }^{3}$ Sinop Arkeoloji Müzesi Kazı Env. No. ORD_2016-03.
} 
çapı 4,4 cm'dir. Ağız kısmı eksik olsa da kabın geriye kalan bölümü tam olarak korunagelmiştir. İki adet kulakçık biçimli tutamak hemen omuz kısmının altında olacak şekilde gövdenin iki yanında yer almaktadır. Özellikle pişmiş toprak benzerlerine boyun ve gövde profili ile sergilediği benzerlikler ışı̆̆ında bu eser MÖ 4. yüzyılın son çeyreği içlerine tarihlenebilmektedir (Karageorghis, 1973, 197, Lev. CC-CCIII, CCII-CCCV; Yılmazer 1995). Aynı açmanın güney kesitinde 1,65 m seviyede olacak şekilde 1 adet pişmiş toprak unguentarium da bulunmuştur. ${ }^{4}$ Boyun ile ağız kısmı eksik olan eser hafif şişkin bir karın, silindirik bir ayak ve yuvarlak bir kaide ile nitelenmektedir (Resim 4:b). Korunagelmiş yüksekliği 11,5 cm iken gövde çapı 4,3 cm'dir. Gövde profili yanında özellikle kaide kısmındaki çentik ile Atina Agorası'nın MÖ 180-100 arasina tarihlenen Kategori 5 tipleri arasına yerleştirilebilecektir (Rotroff, 2006, s. 151, 154). Başka nekropollerde bulunan benzerleri de ağırlıklı olarak MÖ 2. yüzyılın ikinci yarısına tarihlenmiş olmaları bakımından bu çıkarımı desteklemektedir (Henninger ve Kossatz, 1979, Taf. 55,1; Kiz1l, 2009, s. 403-404, Res. 119-121).

Kiremit mezarların üçüncüsü yine aynı açmanın doğu kesitinde 1,40 m. derinlikte açığa çıkarılmıştır (Mezar 3). Söz konusu mezar belli bir bölümünün kesit içinde kalması sebebi ile kesite niş açılarak kaldırılmıştır. Çalışmaların genişletilmesi esnasında 2 No.lu Açma'nın batısına, bir sonra açılması planlanan 3 No.lu Açma'nın ise doğu kesitine denk gelen bir noktada diğer bir mezara daha rastlanılmıştır (Mezar 4). Söz konusu mezar yüzeysel denebilecek kadar yukarı bir seviyede olacak şekilde $0,45 \mathrm{~m}$. derinlikte bulunmuştur. 2 No.lu Açma'da tespit edilen son mezar güney kesitte olacak şekilde $1,1 \mathrm{~m}$. derinlikte açığa çıkarılmıştır (Mezar 5). Taş Sanduka tipindeki bu son mezarın da kazılmasını takiben bu açmadaki çalışmalara son verilmiştir.

Alanda gerçekleştirilen bir sonraki kazı 3 x 3 m ölçülerindeki "3 No.lu Açma” bünyesinde olmuştur. Söz konusu açma, konum olarak 1 No.lu Açma’nın 2 m. güneyinde, 2 No.lu Açma'nın ise $2 \mathrm{~m}$. kuzeyinde yer almaktadır. Gerçekleştirilen çalışmalar esnasında yaklaşık olarak $1 \mathrm{~m}$. derinlikte bir taş sırası açığa çıkmıştır. Taş sırasının kuzey-güney uzantılı yönelimi açmanın her iki yöne doğru genişletilmesine sebep olmuştur. Bu genişleme sonucunda 3 No.lu Açma ile 2 No.lu Açma birleştirilmiştir. Genişleme çalışmaları ile daha büyük bir bölümü açığa çıkarılan taş sırasının düzensiz ve zayıf bir örgü sergileyen bir duvar olduğu anlaşılmıştır. Söz konusu duvar güney kısmında 0,95 m., kuzey kısmında ise $1,1 \mathrm{~m}$. derinlik sergileyerek eğimli bir yapı ortaya koymuştur. Duvarın açığa çıkarılması için gerçekleştirilen çalışmalar esnasında kuzey tarafta $0,70 \mathrm{~m}$. seviyede kısmi bir unguentarium daha bulunmuştur. ${ }^{5}$ Dip kısmı kırık şekilde korunmuş ve boyun-ağız bölümü de eksik olarak ele geçmiş olan unguentarium özellikle iğ biçimli gövdesi ile nitelenmektedir (Resim 4:c). Korunagelmiş yüksekliği $12 \mathrm{~cm}$ olan eserin karın kısmının çap1 5,5 cm'dir. Eserin karın kısmında gri bir astara ait kısmi izler mevcuttur. Özellikle kil yapısı ve gri astarı ışığında Atina Agorası kökenli "gri astarlı unguentarium" grubu altına yerleştirilebilmektedir. Özellikle yekpare şekilde

\footnotetext{
${ }^{4}$ Sinop Arkeoloji Müzesi Kazı Env. No. ORD_2016-04.

${ }^{5}$ Sinop Arkeoloji Müzesi Kazı Env. No. ORD_2016-01.
} 


\section{Sinope Batı Nekropolünden Yeni Bir Gömü Alanı - Ord 2016}

verilmiş kaide-ayak kısmı ve şişkin gövdesi ise aynı grubun "Kategori 6" örnekleri bünyesinde değerlendirilmesini mümkün k1lmaktadır (Rotroff, 2006, s. 154). Agora ve çevre kontekstleri ışığında MÖ 2. ve 1. yüzyıllar arasına dâhil edilen bu formun (Rotroff, 2006, s. 151, 154, 295, No. 477) yekpare kaide-ayak kısmı da MÖ. 2. yüzyılın ikinci yarısı ve sonrası odaklı bir tarih için belirleyici olmaktadır (Rotroff, 2006, 153). Bu çıkarım, yine kontekst kökenli çeşitli paralellerin de MÖ 2. yüzyıl ikinci yarıs1 odaklı tarihleri ile desteklenmektedir (Boulter, 1963, No. 125-1, s. 26, Lev. 26:K 1; Smetana-Scherrer, 1982, s. 89, Lev. 56, No. 717). Aynı duvarın doğu tarafinda ise $1 \mathrm{~m}$. derinlikte olacak şekilde 1 adet gümüş sikke ele geçmiştir. ${ }^{6}$ Sikkenin ön yüzünde İmparator Nero'nun çelenkli portresi, arka yüzünde ise bir ayağıyla küreye basan ve ellerinde stylus ile kalkan taşıyan kanatlı Nike tasviri yer almaktadır (Resim 4:d). Ön yüzde ayrıca "NERO CLAVD DIVI CLAVD F CAESAR AVG GERMANI" lejantı okunabilmektedir. Bu özellikleri ışığında ORD sikkesi kolaylıkla MS 54-68 tarihli Caesarea (Kappadokia) darpları arasina verilebilmektedir (Buinett ve diğ., 1992, s. 3645; Mattingly, 1923, s. 409-410; Sutherland, 1984, s. 617).

Parselin ve aynı zamanda 3 No.lu Açma'nın 2 m. doğusunda yer alan "4 No.lu Açma", 3 x 3 m ölçülerinde açılmıştır. Bu açma bünyesinde ikinci bir taş sırası açığa çıkmıştır. Kavisli bir yapı sunan bu ikinci duvar takip edilerek parsel sınırına kadar gelinmiş ancak parsel dışındaki devamlılığı açığa çıkarılmamıştır. Duvarın açma içindeki kısmı 2,1 m. uzunluğundadır. 4 No.lu Açma'daki çalışmalar 2,5 m. derinlikte ana toprak seviyesine ulaşılması neticesinde sonlandırılmıştır.

Kazılar esnasında ayrıca parsel geneline yayılmış şekilde farklı kodlarda yer alan pek çok amorf seramik parçasına da rastlanılmıştır. Amorf seramikler arasında özellikle kırmızı figürlü lekythoslara, lebes gamikoslara veya siyah glazürlü olpe ile kâse benzeri kaplara ait parçalar dikkat çekmektedir (Resim 5). Bu seramikler alanın bir nekropol olarak kullanımının MÖ 5. ve 4. yüzyıllara olacak şekilde geriye götürülebileceğini göstermektedir.

ORD Kazısı'nın belki de en ilginç buluntularından birine kazı sonrasında bina yapımı için gerçekleştirilen hafriyat çalışması esnasında ulaşılmıştır. Yine Müze arkeologları denetiminde sürdürülen bu çalışma esnasında parselin batı sınırının $0,50 \mathrm{~m}$. dışında bir adet minyatür Dor sütunu biçimli mezar belirteci ele geçmiştir. Sinop'un ada kısmına özgü Boztepe kireçtaşından yapılmış olan sütun yivlere bölünmüş bir gövde üzerinde yükselen bir ekhinus ve abaküs ile nitelenmektedir (Resim 6). Gövde ile ekhinus arasındaki ayrım ince bir bilezik ile vurgulanmıştır. Kabaca 30 x $30 \mathrm{~cm}$ 'lik bir ölçü sunan abaküs, dairesel ve bombeli bir tepe kısmı sergilemesi ile dikkat çekmektedir. Yüksekliği $60 \mathrm{~cm}$. olan sütunun gövde çapı $22 \mathrm{~cm}$ 'dir. Gövde üzerindeki yivlerden ikisi içerisine kazınmış bir yazıt MANTIOEO $\Sigma$ ATO $\Sigma$ [Das('ın oğlu) Mantitheos (burada yatıyor)] ibaresini içermektedir. Nominatif halde şahıs isimleri içeren bu mezar belirtecini, yazıtı teşkil eden harfler 1şı̆̆ında (McLean, 2002, 42) MÖ. 3.-2. yüzyıllara tarihlemek

\footnotetext{
${ }^{6}$ Sinop Arkeoloji Müzesi Kazı Env. No. ORD_2016-05.
} 
mümkündür. ${ }^{7}$ Sütunun üzerine dikildiği mezar sahibi olan Mantitheos'un ismine Sinop'ta bulunmuş başka hiçbir yazıtta rastlanılmamıştır. Diğer yandan "Das" ismi MS. 1-2. yüzyıllar arasına tarihlenmiş bir stel üzerinde olacak şekilde tek bir örnekle karşımıza çıkmaktadır (French, 2004, s. 100, No. 138). Sinop kökenli yazıtları incelediği çalışmasında French (2004, s. 165, No. 138) "Das" ismini Paphlagonia kökenli olarak kabul etmiştir. Bundan çıkışla ORD sütunu üzerindeki Mantitheos'un babası Das'ın da bir Paphlagonialı veya Sinopeli olduğu öne sürülebilecektir. Bunun neticesinde mezarın asıl sahibi Mantitheos'un da yine yerel halktan olduğu anlaşılmaktadır.

Yukarıdaki satırlarda anlatıldığı şekli ile ORD 2016 kazısı bünyesinde açılan toplam dört açmada farklı tiplerde olacak şekilde 5 adet mezar tespit edilmiştir. Ayrıca çeşitli mimari kalıntılar ile bazı başka buluntular da açığa çıkarılmıştır. Özellikle mimari kalıntıları teşkil eden taş duvarların herhangi bir yapıya ait olmadığı kesindir. Mezarlar bünyesinde ulaşılmış olup bir sonraki başlık altında irdelenecek olan eserler hiç şüphesiz gömülere eşlik eden buluntulardır. Mezarlar dışında tespit edilmiş olan 2 adet unguentarium, 1 adet alabastron, 1 adet sikke ve Dor sütunu biçimli mezar belirtecini ise herhangi bir mezara vermek mümkün değildir. Yine de tüm bu eserlerin şüphe götürmez bir şekilde gömü alanında yer alan başka mezarların içlerinden veya çevrelerinden geldiği kolaylıkla söylenebilecektir.

\section{Mezarlar ve Buluntuları}

Daha önce de belirtildiği üzere, 2016 yılında gerçekleştirilmiş olan kazı kapsamında söz konusu parselde sadece tek bir açma içerisinde olacak şekilde toplamda 5 adet mezar açığa çıkarılmıştır. Mezarlardan bir tanesi inhumasyon, üç tanesi kiremit mezar ve bir tanesi de taş sanduka mezar şeklindedir. Her bir mezarın tipolojisi ve buluntu repertuvarlarının detaylı bir incelemeye tabi tutulması bu gömü alanının kimliklendirilmesi ve tarihlenmesi adına önem arz etmektedir.

\subsection{Mezar 1}

Doğrudan ana toprak üzerine oluşturulmuş olan Mezar 1, düz semerdam kiremit mezar tipindedir (Resim 7). Kuzeybat1-güneydoğu uzantılı mezar, 0,95 m uzunluğunda ve $0,65 \mathrm{~m}$ genişliğindedir. Teşkil edilmesinde uzun kenarlarında belirgin bir profil sunan düz çatı kiremitlerinden yararlanılmıştır. Kırık olmalarına rağmen kiremitlerden dört tanesinin birbiri üzerine çatılmak suretiyle, beşincisinin ise dik şekilde mezarın başına koyularak kullanıldığı anlaşılmaktadır. Benzerlerinden de iyi bilindiği üzere diğer uçta da mevcut olması gereken dik yerleştirilmiş ikinci kiremit korunagelmemiştir (Uygulamanın benzerleri için bkz. Kasapoğlu, 2007, Res. 16-18, 20-22; Ürkmez, 2014, Res. 4\&5).

Mezar içerisindeki iskelet oldukça kötü korunmuş bir şekilde açığa çıkmıştır. Neredeyse tüm kemikleri erimiş olan iskeletin, ancak bazı kafatası parçaları tespit edilebilmiştir. Bu sayede mezar sahibinin, başı kuzeybatıya gelecek

\footnotetext{
7 Yazıtın çevirisini gerçekleştirip tarihlemesi hususunda da ayrıca paylaşımda bulunan Prof. Dr. Cumhur TANRIVER ve Prof. Dr. Mustafa H. SAYAR'a teşekkür ederim.
} 


\section{Sinope Batı Nekropolünden Yeni Bir Gömü Alanı - Ord 2016}

şekilde defnedildiği söylenebilecektir. Sol omuz civarında bulunmuş olan 14 adet konik boncuk tanesinden mezar sahibinin en azından bir kolye ile defnedildiği anlaşılmaktadır (Resim 8). ${ }^{8}$ Mezarda başka hiçbir buluntu ele geçmemiştir. Mezarın teşkil edilmesinde kullanılan kiremitler, ilerde de görüleceği üzere, Sinop'a yakın Amisos nekropolü (Ünan, 2013, s. 391) dışında diğer pek çok nekropolde açığa çıkarılmış olan benzerleri ışığında da kolaylıkla Hellenistik Dönem'e tarihlenebilecektir (Dusenbery, 1998: s. 25-39; Hürmüzlü, 2008, s. 22-23, Res. 14; Kasapoğlu, 2007, s. 488-489; Kasapoğlu, 2015, s. 123-124, Figs. 154 \& 155; Kurtz ve Boardman, 1971, s. 73-74; Şahin, 2018, s. 124-125, No. 2798, Res. 17; Ürkmez, 2014, s. 338-341). Bu sayede fazla buluntu içermemesine rağmen Mezar 1'in de Hellenistik Dönem'e tarihlenmesi mümkün olmaktadır.

\subsection{Mezar 2}

Mezar 2, yine semerdam kiremit mezar tipinde olsa da aşırı derecede zarar görmüş yapısı sağlıklı bir şekilde yorumlanmasını mümkün kılmamaktadır. Mezarda kullanılmış kiremitler oldukça kötü şekilde kırılmış, mezarın çatma yapısı tamamen ortadan kalkmış ve gömünün bütünlüğü de bozulmuştur (Resim 9). Kısmen ele geçmiş olan iskeletten gömünün kuzeydoğu-güneybatı uzantılı olduğu söylenebilmektedir. Mezar içerisinde veya etrafında hiçbir buluntuya rastlanılmamıştır. Yine de kiremitlerin sergilediği tipolojik benzerlikler bu mezarın da Mezar 1 ile çağdaş olacak şekilde Hellenistik Dönem'e ait olduğunu göstermektedir.

\subsection{Mezar 3}

Mezar 3, ORD gömü alanında bulunmuş olan semerdam kiremit mezarların sonuncusu ve en iyi şekilde korunmuş olanıdır (Resim 10). Doğu-batı uzantılı bu mezar kot olarak Mezar 2'den yukarda olması ile dikkat çekmektedir $(1,40 \mathrm{~m})$. Çatma örgüsünün bütünlüğü korunmuş olsa da, kiremitlerinin hepsi içe çökmüş veya kırılmış bir şekilde ele geçmiştir. Mezarın başına ve sonuna dik olarak yerleştirilmiş birer dikdörtgen kiremit dışında çatma örgüyü teşkil etmek adında 8 adet daha kiremitten yararlanılmıştır. Kiremitler, Mezar 1 ve 3 'te kullanılmış olanlar ile bir örnektir.

Kiremitlerden teşkil edilmiş olan çatkının altına gerçekleştirilmiş olan gömü, oldukça zarar görmüş ve bazı parçaları kiremitlere yapışacak şekilde ezilmiş tek bir iskeletten ibarettir. Kötü korunma durumuna rağmen iskeletin başı doğuya gelecek şekilde yerleştirildiği açıktır. Mezar 3, ORD dâhilindeki benzerlerine kıyasla daha çeşitli bir gömü repertuvarı da sunmaktadır. Öyle ki mezar sahibinin omuzları üzerine bırakılmış birbirinin eşi iki adet bodur lekythosa ek olarak sol kalça yanında da oldukça kötü korunmuş tek bir tunç yüzük kaşı bulunmuştur.

Mezar 3'ün buluntu repertuvarını teşkil eden lekythoslardan biri sağlam çıkarılmış tamamen kırık bulunan diğeri ise sonradan birleştirilmiştir. Büyük oranda sağlam olan ilk lekythosun korunagelmiş yüksekliği 7,6 cm, gövde çapı ise 4,5 cm

\footnotetext{
${ }^{8}$ Sinop Arkeoloji Müzesi Kazı Env. No. ORD_2016-02.
} 
olarak ölçülmüştür (Resim 11:b). ${ }^{9}$ Tamamen kırık olarak ele geçmiş ancak sonrasında birleştirilmiş olan ikinci lekythos tam ölçü verecek şekilde $8,6 \mathrm{~cm}$ yüksekliğindedir (Resim 11:a). Gövde çapı yine 4,5 cm iken ağız çapı 3,1 cm'dir. Siyah firnisli boyun ve kulp ama en çok da ağ desenli küresel gövdeleri her iki örneği de karakterize eden başlıca özelliklerdir. Sergiledikleri bu özellikler ışığında her iki lekythosu da iyi bilinen "ağ desenli bodur lekythoslar" altında değerlendirmek mümkün olacaktır. Dış merkezlerdeki pek çok nekropolde yoğun örneklerle temsil edilen (Goldman, 1950, s. 152, Lev. 119:21; Kotitsa, 2012, s. 87, 89 \& 90 figs. 12, 14, 20; Robinson, 1933, s. 183, Lev. 147:488), ayrıca Sinop'ta açığa çıkarılmış diğer mezarlarda da benzerlerine rastlanılan bu form (Kaba, 2019, s. 179, 181, Fig. 6) ağıllıklı olarak MÖ. 4. yüzyılın son çeyreği tarihli kontekstlerden gelmektedir. Lekythosların sunduğu mutlak tarihin aksine yüzük kaşı kötü korunma durumu ve sade yapısı neticesinde tarihlemeye hiçbir katkı sağlayamamıştır.

Ölünün vücudunu yıkamak için kullanılan kokulu sıvıları/yağları barındıran lekythoslar doğrudan ölü gömme ile alakalı formlardır (Kurtz ve Boardman, 1971, s. 209; Moore, 1997, s. 45). Bundan yola çıkışla, her iki örneğin de gömü esnasındaki libasyon törenlerinde kullanıldığı açıktır. Böylece sağladıkları Erken Hellenistik Dönem odaklı tarih (MÖ 325-300) Mezar 3 için kabul edilebilir bir tarih olmaktadır.

\subsection{Mezar 4}

Diğer mezarlara kıyasla oldukça yüksek kotta yer alacak şekilde 0,45 m'de açığa çıkarılmış olan Mezar 4, ORD bünyesindeki tek inhumasyon gömüdür. Doğrudan ana toprak üzerine, baş güneyde olacak şekilde kuzey-güney doğrultulu gerçekleştirilmiştir. Hiçbir buluntu içermeyen bu mezarda rastlanılan iskelet oldukça iyi korunmuş olması ile dikkat çekmektedir. Belli tipte bir mezar yapısına ve buluntuya sahip olmayan bu mezarın tarihlemesi gerçekleştirilememiştir.

\subsection{Mezar 5}

Parseli kuzey yönünde sınırlandıran kesitin hemen dibinde olacak şekilde $1 \mathrm{~m}$ kotta bulunmuş olan Mezar 5 taş sanduka mezar tipindedir. Farklı ebat ve kalınlıklarda üç adet plakanın yan yana dizilmesi ile kapatılmış bir şekilde bulunmuştur (Resim 12). Kuzeydoğu-güneybatı uzantılı mezarın tekne kısmı ise kireçtaş1 plakalar kullanılarak ana toprak üzerine oluşturulmuştur. Mezarın uzun kenarları $0,20 \mathrm{~m}$ kalınlığında ve 1,85 m uzunluğunda birer plakadan; kısa kenarları ise $0,10 \mathrm{~m}$ kalınlığında ve $0,80 \mathrm{~m}$ uzunluğunda birer plakadan teşkil edilmiştir (Resim 13). Plakaların toprağa gömülmek suretiyle sabitlendiği ve bir araya getirilmelerinde bağlayıcı hiçbir öğeden yararlanılmadığı anlaşılmaktadır. Bunun tersine kapamada kullanılan plakalar arasında bağlayıcı öğe olarak kireçli bir harç kullanıldığı tespit edilmiştir. Mezar içerisindeki gömü, doğrudan sertleştirilmiş ana toprak üzerine gerçekleştirilmiştir. Birkaç kemik dışında tamamen kaybolmuş olan iskelet dışına ele geçen buluntular 2 adet testicik ve 1 adet tunç sondadan ibarettir.

\footnotetext{
${ }^{9}$ Sinop Arkeoloji Müzesi Kazı Env. No. ORD_2016-07.
} 


\section{Sinope Batı Nekropolünden Yeni Bir Gömü Alanı - Ord 2016}

Eserlerin tümü bir grup halinde kuzeydoğu köşeye bırakılmış şekilde ele geçmiştir (Resim 14).

Mezar 5, pek çok farklı coğrafyada olacak şekilde değişik biçim ve boyutlardaki benzerleri ışı̆̆ında iyi bilinen bir mezar tipini örneklemektedir (Körpe 1997, 171-194; Özkan ve Atukeren 1999: 44, Res. 45; Polat 2005, 85-88; Serdaroğlu

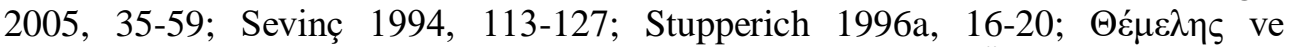

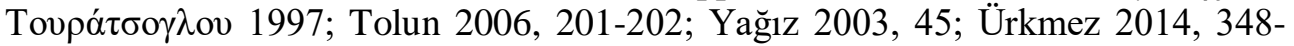
349). Yine de Mezar 5 'in pek çok paraleline kıyasla biraz daha özensiz bir işçilik sergilediği söylenebilecektir. Öyle ki, neredeyse hiçbir plakanın kesiminde özenli bir çalışmaya gidilmemiş, şekillendirmeler kabaca yapılmış ve özellikle kapama taşlarının kalınlıkları değişkenlik gösterecek şekilde bırakılmıştır. Mezarın mutlak tarihlemesinde, sergilediği tipolojik özelliklerden çok buluntu envanteri rol oynamaktadır.

Birbirlerine yakın bir şekilde bulunmuş testicikler bu bağlamda en önemli veriyi sunmaktadır. Temelde Hellenistik Dönem'in sevilen formu lagynoslardan türemiş olsalar da bu kaplar ağırlıkla "testicik" veya "sürahi" adı altında değerlendirilmektedir (Hayes, 1997, s. 76). Mezar 5'te ele geçiş olan lagynos kökenli testicik keskin bir açıyla içe eğimlenen ağız kenarı, boyna doğru inceldikten sonra karın kısmına doğru bir şişkinlik sunan profili, tek kulbu ve halka kaidesi ile iyi bilinen bir formu örneklemektedir (Resim 15:a). ${ }^{10}$ Yüksekliği 15,5 cm olan kap 4,9 cm'lik bir ağız çapı ve $10 \mathrm{~cm}$ 'lik bir gövde çapına sahiptir. Hem ağız hem de gövde profili ışığında bulduğu kısmi paralellikler sayesinde kolaylıkla MÖ 1. Yüzyılın sonlarına tarihlenebilecektir (Besuden ve diğ. 1998-1999, Abb. 20:81; Coldstream ve diğ. 2001, s. 154, Fig. 9; Py, 1993, s. 227, fig. CL-REC 74). Bunun dişında Hayes (1997, s. 75-76) bu formların özellikle MÖ. Geç 1. yüzyıl ama aynı zamanda MS. Erken 1. yüzyıl arasında da popüler olduğuna açıkça değinmektedir.

İkinci testicik, ilk örneğe kıyasla bazı formsal değişiklikler sunmaktadır (Resim 15:b). ${ }^{11}$ Ağızdan karın kısmına kadar olan üst bölüm tamamen daldırma tekniği ile astarlanmış olup astarın kahverengimsi bir renkte olduğu görülmektedir. Ağız kenarı dışa açılan bir profil sağlamakta iken bir önceki örnekteki keskin açılı karın profili yerini daha yumuşak açılarla nitelenen bir forma bırakmıştır. Testicik, düz bir dip üzerine oturmaktadır. Yüksekliği $13,3 \mathrm{~cm}$ olan kap 4,6 cm'lik bir ağız çap1 ile $8,7 \mathrm{~cm}$.'lik bir gövde çapına sahiptir. Mezar 5'te bulunmuş olan ikinci testicik hem gövde hem de ağız profili ile bulduğu benzerler ışığında MÖ 1. yüzyılın sonlarından başlayarak MS 1. yüzyılın ortalarına kadar uzanabilen bir tarih vermektedir (Besuden ve di ğ. 1998-1999, Abb. 19: 77, 21: 83-85, 23: 89; Py, 1993, s. 229, Fig. CL-REC 4d).

Tunç sonda, mezar içerisinde kendisine sahibinin gündelik hayatında kullandığı bir kişisel bakım/sağlık aleti olarak yer bulmuş olmalıdır (Baykan, 2009, s. 38)(Resim 15:c). ${ }^{12}$ Alt bitiminin sivri bir uçla nitelendiği eserin diğer bitimi ise kaşık formlu bir uçla sonlanmaktadır. Benzerlerinin ağırlıkla Roma İmparatorluk

\footnotetext{
${ }^{10}$ Sinop Arkeoloji Müzesi Kazı Env. No. ORD_2016-08.

${ }^{11}$ Sinop Arkeoloji Müzesi Kazı Env. No. ORD_2016-09.

${ }^{12}$ Sinop Arkeoloji Müzesi Kazı Env. No. ORD_2016-10.
} 
Dönemi'ne tarihlendiği bu eserin (Arslan, 2013, s. 130; Atakan, 2002, Kat. 6; Baykan, 2009, Kat.8, 15, 17, 19, 26, 47\&48; Bliquez, 2003, Fig.3/30\&31; Gürler, 2004, Kat. 42; Künzl, 1999, Taf. 16/9; Künzl, 2002, Fig. 59; Şahin, 2010, Kat. No: G9-G10; Zampieri, 1997, Kat. 85; Zampieri-Lavarone, 2000, Kat. No:266f;) özellikle Parion'da bir mezar kontekstinden gelen benzeri 1şığında MÖ 1. yüzyıl içlerine de tarihlenebileceği anlaşılmaktadır (Çelikbaş 2015, 137, Kat No. E33).

Mezar 5 repertuvarındaki seramik buluntuların MÖ 1. ve MS 1. yüzyıl arasına yayılan bir tarih verdiği gözlemlenmektedir. Diğer bir buluntu olan tunç sondanın da en erken olacak şekilde MS 1. Yüzyıla ve sonrasına tarihlenebileceği görülmektedir. Tüm eserlerin tarihsel anlamda kesişme noktasını teşkil eden MS 1. yüzyıl, büyük ihtimalle de bu yüzyılın ilk yarısı, Mezar 5 için kabul edilebilir bir kapanma tarihi olacaktır.

\section{Değerlendirme ve Sonuç}

ORD 2016 kapsamında gerçekleştirilen kazılarda açığa çıkarılmış olan alanın büyük bir nekropolün belli bir bölümünü teşkil ettiği açıktır. Kente ulaşımı sağlayan boğazın güney tarafinda yer alan bir nekropolün mevcudiyeti, hemen ORD'nin 50 m güneybatısındaki Roma-Geç Roma tarihli "Gelincik Mezar Odası" sayesinde de anlaş1labilmektedir (Kaba ve Vural, 2018, s. 447-449). Bölgenin geneline yayılmış bir nekropol çıkarımı ayrıca Sinop'ta gerçekleştirilen ilk bilimsel kazılar sayılan TTK Kazıları tarafindan da perçinlenmektedir. Öyle ki TTK Kazıları bünyesinde gerçekleştirilen çalışmalar ORD'den 300 m kuzeydoğudaki "Bahçeler Mevki”nde Geç Klasik Dönem tarihli bir heykeltıraşlık eseri ortaya çıkarmıştır. Anıtsal nitelikli bir mezarı süslemede kullanılmak üzere yontulmuş olduğu anlaşılan bu eserde bir geyik-aslan mücadelesi sahnesi işlenmiştir (Budde, 1956a, s. 7, Lev. III ). Yine aynı bölgeden geldiği bilinen yazıtlı bir Dor sütunu biçimli mezar belirteci de bu bölgedeki bir nekropol alanın diğer bir kanıtı olarak sayılabilir (French, 2004, s. 14, No. 9). Tüm bu veriler, boğazın güneyi boyunca uzanan yamaçlar ile deniz arasındaki alana yayılmış hatırı sayılır büyüklükte bir nekropol alanının başlıca göstergeleridir. Bu çalışmanın konusunu teşkil eden ORD gömü alanı da hiç kuşkusuz bu büyük nekropolün belli bir bölümüne ait olmalıdır.

Hemen hemen yakın zaman aralıkları ile teşkil edilmiş olan dört mezarın (Mezar 1, 2, 3 ve 5) birbirlerinden farklı kotlarda oluşu ORD'nin farklı yükseltilerle nitelenen bir topoğrafyaya sahip olduğunun kanıtlarıdır. Mezarlar ışığında ortaya çıkan bu topoğrafik yapı, açmalar içerisinde bulunmuş olan basit örgü duvarları da anlamlandırmamızı kolaylaştırmaktadır. Herhangi bir yapıya ait olamayacak şekilde zayıf ve devamsız örgüler sunan bu duvarlar, civarlarında açı̆̆a çıkmış olan buluntular ışığında da (unguentarium ve gümüş hemidrakhmi) doğrudan gömü alanı ile ilişkilendirilebilmektedir. Gömü alanına aidiyetleri bu buluntular ile de desteklenen duvarlar, topoğrafik yapı ile beraber ele alındıklarında ikisinin de ya bir nevi teras veya sınır duvarı olabileceği akla gelmektedir. Öyle ki benzer duvar örgülerine, topoğrafik düzenlenişleri ORD'deki gibi eğim üzerine kurulmuş olan başka nekropollerde hem set duvarı şeklinde (Stupperich, 1996a, s. 9-10) hem de 


\section{Sinope Batı Nekropolünden Yeni Bir Gömü Alanı - Ord 2016}

alan sınırı belirlemek için kullanılacak şekilde (Stupperich, 1996b, s. 65-66) rastlanılabilmektedir.

ORD bünyesindeki beș mezardan iki tanesi kontekstleri ışığında diğer iki tanesi ise teşkil edilmelerinde kullanılan kiremitler 1şı̆̆ında tarihlendirilebilmiştir. Bu mezalardan Mezar 1, 2 ve 3 Erken Hellenistik Dönem'e tarihlenmiştir. Mezar 5 için verilebilecek en sağlıklı tarih ise MS. 1. yüzyılın ilk yarısıdır. Her iki tarih de ayrıca mezarlar dışından gelmiş unguentariumlar kadar Caesarea darbı gümüş sikke ile de desteklenmektedir. Diğer yandan mezarlar dışından gelmiş kırmızı figürlü veya siyah glazürlü kaplara ait amorf parçalar bu gömü alanının erken evrelerini MÖ. 5-4. yüzyıllara kadar götürmeyi mümkün kılmaktadır. Bu tarihlemeler ışığında bu parsel dışında yakın civarındaki kazılmamış parsellerin de bile, Sinope'nin KlasikErken Roma Dönemleri'ne 1 ş1k tutacak derecede önem arz ettiği ileri sürülebilecektir.

Mezarlarda ve gömü alanı bünyesinde bulunmuş olan eserler sıra dışı bilgiler sunmayan alışılıış nekropol buluntuları olarak dikkat çekmektedir. Ancak, bu hususta özellikle üzerinde durulması gereken eser hiç kuşkusuz minyatür Dor sütunu formlu mezar belirteci olacaktır. Parsel dışında ele geçen bu buluntu, Sinop'ta yaklaşık olarak 130 adet benzerle temsil edilen bu tipteki mezar belirteçlerinin bazı mezarlar ile bulunmuş yegâne örnekleyicisidir (French 2004). Üzerindeki yazıttan Mantitheos isminde bir adamın mezarı üzerine dikilmiş olduğu anlaşılan bu minyatür sütun, etrafta keşfedilmeyi bekleyen daha başka mezarların varlığına işaret etmesi bakımından önemlidir. Özellikle mezar kontekstleri bağlamında ele alındıklarında, ORD mezarlarının Hellenistik ve Erken Roma Sinopesi'nin sıradan vatandaşlarına ait olduğu anlaşılmaktadır.

ORD 2016 kapsamında tespit edilmiş olan bu gömü alanı, çalışma bünyesinde hem lokal hem de çevresel bağlamda irdelenmiştir. Alanın kendi içindeki değerlendirmesi açığa çıkarılmış olan mezarlar, bu mezarların buluntuları kadar etraftaki kalıntılar veya buluntular ile de sağlanmaya çalışılmıştır. Topoğrafik yapı ile önceki kazılarda tespit edilmiş yakın ve uzak civardaki diğer mezar/mezar kalıntıları ise ORD'nin çevresel değerlendirmesinde kullanılmıştır. Kısıtlı ölçülerdeki bir alanda tespit edilmiş olan az sayıdaki mezar ve buluntuya rağmen ORD’nin daha büyük bir nekropolün küçük bir bölümünü teşkil ettiği aşikârdır. Yine de bu alanın bizlere Hellenistik - Erken Roma gömü alanları hakkında kabul edilebilir nitelikte veriler sunduğu söylenebilecektir. Bu potansiyelden yola çıkışla özellikle etraftaki parsellerin sistematik kazılar ile araştırılması gerekliliğinin doğduğu da söylenebilecektir. Bu parsellerde gerçekleştirilecek kazıların, denize bakan yamaçlar üzerine konuşlanmış olan adını ve gerçek potansiyelini henüz bilmediğimiz bu nekropolün daha iyi anlaşılmasına değerli katkılar sunacağı kesindir. 


\section{Eray AKSOY}

\section{Kaynakça}

Angermeier, H.E. (1936). Das alabastron. Giessen: Buchdruckerei Richard Glasgow.

Arslan, M. (2013). The Museum of Anatolian Civilizations: A guide to Ankara throughout the ages. Ankara: Alter Yayıncilik.

Atakan, N. (2002). Anadolu' da tıp aletleri ve araç gereçleri. N. Atakan ve Z. Kızıltan (Yay. haz.). Ístanbul Arkeoloji Müzeleri geçmişten günümüze tıp sergisi içinde (117). İstanbul: Kültür Bakanlığı Anıtlar ve Müzeler Genel Müdürlügüü.

Besuden, Y., Biller, F., Christeleit, K., Dretschak, C., van Endert, T., Fischer, E., Hamelmann, J., Hasenjager, S., Kenzler, H., Muller, M., Panhans, T., Schafer, S., Schafranitz, M. (1998-1999). Katalog romischer gefasse und lampen aus den Nordwest-Provinzen. Boreas, 21-22, s. 333-383.

Bliquez, L. (2003) Roman surgical spoon-probes and their ancient names. The Journal of Roman Studies, 16, s. 322-330.

Boulter, C. G. (1963). Graves in Lenormant Street, Athens. Hesperia, 32.2, s. 113 137.

Budde, L. (1956). Kurzer vorläufiger bericht über die grabungen in Sinope der kampagnen 1951-1953. Türk Arkeoloji Dergisi 6.2, s. 5-10.

Burnett, A., Amandry, M. ve Ripollès, P.P. (1992). Roman provincial coinage. Vol. I: From the death of Caesar to the death of Vitellius (44 BC - AD 69). London: British Museum Press.

Coldstream, J.N., Eiring, L.J. ve Forster, G. (2001). Knossos pottery handbook greek and roman. London: British School at Athens.

Baykan, D. (2009). Allianoi tıp aletleri (Yayımlanmamış DoktoraTezi). İstanbul Üniversitesi. Sosyal Bilimler Enstitüsü. Arkeoloji Ana Bilim Dalı. Klasik Arkeoloji Bilim Dal1. İstanbul.

Dusenbery, E.B. (1998). The nekropoleis - The nekropolies and catalogues of burials. Samothrace Vol. II. New Jersey: Princeton University Press.

French, D. (2004). The inscriptions of Sinope I. Bonn: Dr. Rudolf Habelt GMBH.

Goldman, H. (1950). Excavations at Gözlü Kule, Tarsus I - The hellenistic and roman period. Priceton: Princeton University Press.

Gürler, B. (2004). Tire Müzesi bronz eserleri. İstanbul: Ege Yayınları.

Hayes, J.W. (1997). Handbook of Mediterranean roman pottery. Oklahoma: University of Oklahoma Press.

Henninger, F. J. ve Kossatz, A. U. (1979). Zwei hellenistische gräber der Milesischen nekropole. Istanbuler Mitteilungen, 29, s. 174-186.

Hürmüzlü, B. (2008). Eski Yunan'da ölü gömme gelenekleri. İstanbul: TEBE Yayınları.

Kaba, H. (2019). Rethinking the plakettenvasen from Sinope: New perspectives on the dating, meaning and use of an extraordinary ceramic ware. H. Kaba, G. Kan Şahin, B.M. Akarsu ve O. Bozoğlan (Yay. haz.). Proceedings of the international symposium on Sinope and the Black Sea, 13-15 October 2017, Sinop içinde (s. 177193). Sinop: Şimal Ajans. 


\section{Sinope Batı Nekropolünden Yeni Bir Gömü Alanı - Ord 2016}

Kaba, H. ve Vural, H. (2018). Arkeoloji ile geçen yetmiş yıl - Kazılar 1şı̆̆ında Sinop arkeolojisi. Ö. Kıran (Yay. haz.). Sosyal bilimciler gözüyle Sinop içinde (s. 439-464). Ankara: Berikan Yayıncilık.

Kanowski, C.C.G. (1983). Containers of classical greece. New York: University of Queensland Press.

Karageorghis, V. (1973). Excavations in the necropolis of Salamis III. Nicosia: Department of Antiquities, Cyprus.

Kasapoğlu, H. (2007). Parion nekropolü mezar tipleri. B. Can ve M. Işıklı (Yay. haz.). Doğudan yükselen ışık - arkeoloji yazıları içinde (s. 481-520). İstanbul: Ege Yayınlar1.

Kasapoğlu, H. (2015). VII. Necropolis. C. Başaran (Yay. haz.). The flourishing city of ancient Troad: Parion -

surveys, excavation and restoration works carried out between 1997-2009 içinde (s. 107-134). İstanbul: Ege Yayınlar1.

Kız1l, A. (2009). 1990-2005 yılları arasında Mylasa'da kurtarma kazıları yapılan mezarlar ve buluntuları üzerine genel bir değerlendirme. Die Karer und die Anderen, Internationales Kolloquium an der Freien Universität Berlin 13. Bis 15. Oktober 2005 (s. 397-461) içinde. Bonn: Rudolf Habelt Verlag.

Kotitsa, Z. (2012). Tombes d'enfants du IVe s. av. J.-C. à Pydna. A. Hermary ve C. Dubois (Yay. haz.). L'Enfant et la mort dans l'antiquité III: Le matériel associé aux tombes d'enfants. Actes de la table ronde internationale organisée à la Maison Méditerranéenne des Sciences de l'Homme (MMSH) d'Aix-en-Provence, 20.-22. Janvier 2011 içinde (s. 77-95). Arles: Ed. Errance.

Körpe, R. (1997). 1996 Lapseki kurtarma kazısı. VIII. Müze Kurtarma Kazıları Semineri, s. 171-194.

Kurtz, D.C. ve Boardman, J. (1971). Greek burial customs. London: Thames and Hudson.

Künzl, E. (1999). Arzte in Ephesos: graber und instrumante. Fiesinger, H., Krinzinger, F., Brandt, B. ve Krierer, K.R. (Yay. haz.). 100 jahre österrichische forshungen in Ephesos: aktes des symposions Wien 1995 içinde (s. 205-209). Wien: Verlag der Österreichischen Akademie der Wissenschaften.

Künzl, E. (2002). Medizin in der antike: Aus einer welt ohne narkose und aspirin. Stuttgart: Wbg Theiss.

Mattingly, H. (1923). Coins of the Roman Empire in the British Museum. Vol. 1: Augustus to Vitellius. London: Longmans and Co.

McLean, B.H. (2002). An introduction to greek epigraphy of the hellenistic and roman periods from Alexander the Great down to the reign of Constantine (323 BC - AD 337). Ann Arbour: The University of Michigan Press.

Moore, M.B. (1997). Attic red-figured and white-ground pottery. The Athenian Agora Vol. 30. New Jersey: Princeton Academic Press.

Özkan, T. ve Atukeren, S. (1999). Cevizcioğlu Çiftliği Nekropolü kazıları. T. Özkan ve H. Erkanal (Yay. haz.). Tahtalı Barajı kurtarma kazısı projesi/Tahtalı Dam area salvage project içinde (s. 43-54). İzmir: Kültür Bakanlığı Yayınları. 


\section{Eray AKSOY}

Polat, B. A. (2005). Troia'nın hellenistik ve roma dönemi nekropolleri. (Yayımlanmamış Yüksek Lisans Tezi). İstanbul Üniversitesi, Sosyal Bilimler Enstitüsü.

Py, M. (1993). Ceramique a pate claire recente. M. Py (Yay. haz.). DICOCER Dictionaire des ceramiques antiques Mediterranee nord-occidentale. Lattara 6 içinde (222-243). Lattes: 1'Unité Propre de Recherche 290 du C.N.R.S.

Robinson, D.M. (1933). Mosaics, vases and lamps of Olynthus. Excavations at Olynthus V. Baltimore: The Johns Hopkins Press.

Rotroff, S. (2006). Hellenistic pottery - The plain wares. The Athenian agora vol. XXXIII. Michigan: Edwards Brothers.

Serdaroğlu, Ü. (2005). Behramkale-Assos. İstanbul: Arkeoloji ve Sanat Yayınları.

Sevinç, N. (1994). Tenedos kurtarma kazısı. V. Müze Kurtarma Kazıları Semineri, s. 113-127.

Smetana-Scherrer, R. (1982) Spätklassische und hellenistische keramik. H. Walter (Yay. haz.) Alt-Ägina II.1 içinde (s. 56-91). Mainz am Rhein: Philipp von Zabern.

Stupperich, R. (1996). Vierter vorbericht über die grabung in der westtor-nekropole non Assos im sommer

1992. Ü. Serdaroğlu ve R. Stupperich (Yay. haz.). Ausgrabungen in Assos 1992. Asia Minor Studien 21 içinde (s. 1-31). Bonn: Dr. Rudolf Habelt GMBH.

Sutherland, C. (1984). The roman imperial coinage. Vol. I: From 39 BC to AD 69. London: Spink and Son.

Şahin, F. (2010). Patara metal buluntuları (Yayımlanmamış Yüksek Lisans Tezi). Akdeniz Üniversitesi. Sosyal Bilimler Enstitüsü. Arkeoloji Anabilim Dalı. Antalya. Şahin, M. (2018). Apollonia nekropolü kurtarma kazıları 2016-2017 mezar tipleri üzerine bir inceleme. Uluslararası Türkçe Edebiyat Kültür Eğitim Dergisi, 7(4), s. 2788-2812.

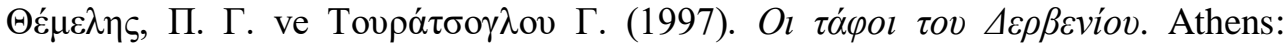

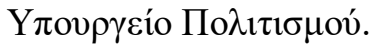

Tolun, V. (2006). Assos nekropolünden klasik dönem atlı heykelcikleri. T. Takaoğlu (Yay. haz.). Anadolu arkeolojisine katkılar - 65. yaşında Abdullah Yaylalı'ya sunulan yazılar içinde (s. 201-206). İstanbul: Hitit Colour.

Ünan, S. (2013). Tunç çağı'ndan roma dönemi'ne, Amisos ve çevresinde yer alan mezar tipleri ve ölü gömme adetleri üzerine genel bir değerlendirme. Ş. Dönmez (Yay. haz.). Güneş Karadeniz'den doğar - Sümer Atasoy'a armăgan yazllar içinde (s. 385-412). Ankara: Hel Yayınları.

Ürkmez, Ö. (2014). Aiolis Kymesi'nden Samurlu 877 nekropolisi. Colloquium Anatolicum, XIII, s. 337-381.

Yağı, K. (2003). Antandros Melis Nekropolü ölü gömme adetleri (Yayınlanmamış Lisans Tezi). Ege Üniversitesi. Edebiyat Fakültesi. Arkeoloji Bölümü.

Yılmazer, H. (1995). Anadolu'da alabstronlar (Yayımlanmamış Doktora Tezi). Konya Selçuk Üniversitesi. Sosyal Bilimler Enstitüsü.

Zampieri, G. (1997). "Gioielli” del Museo Archeologico di Padova: vetri, bronzi, metalli preziosi, ambre e geme. Padova. 
Zampieri, G. ve Lavarone, B. (2000). Bronzi antichi del Museo Archeologico di Padova. Roma: L'Erma di Bretschneider.

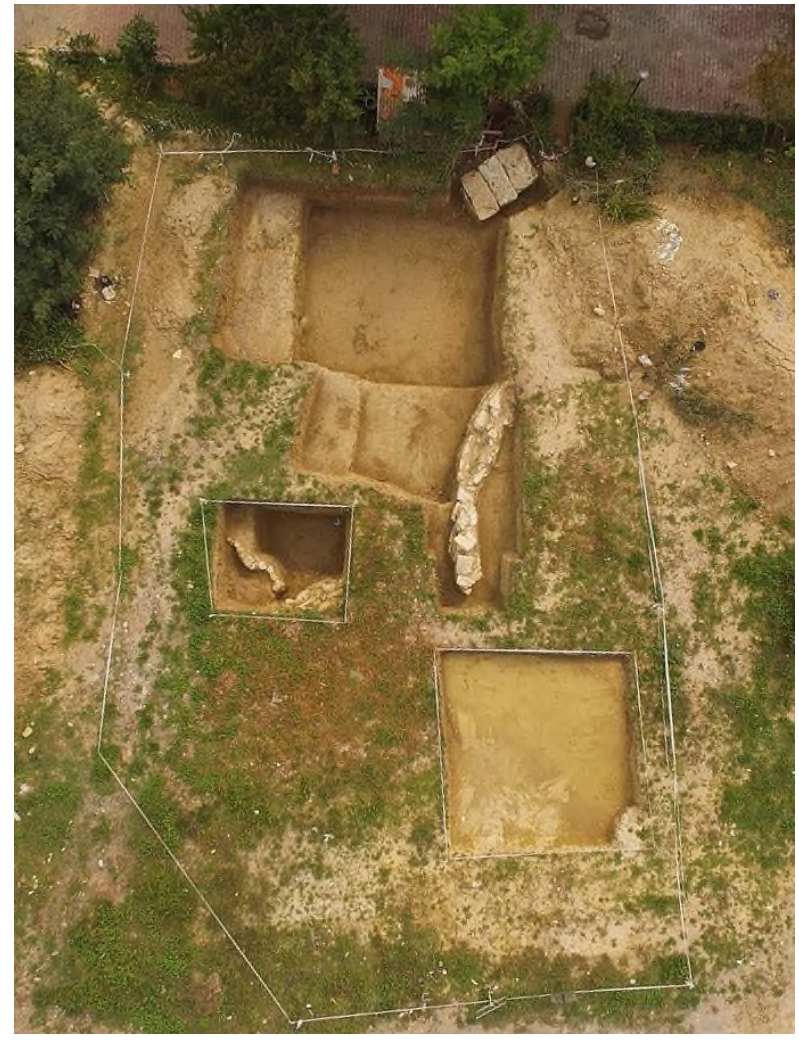

Resim 1

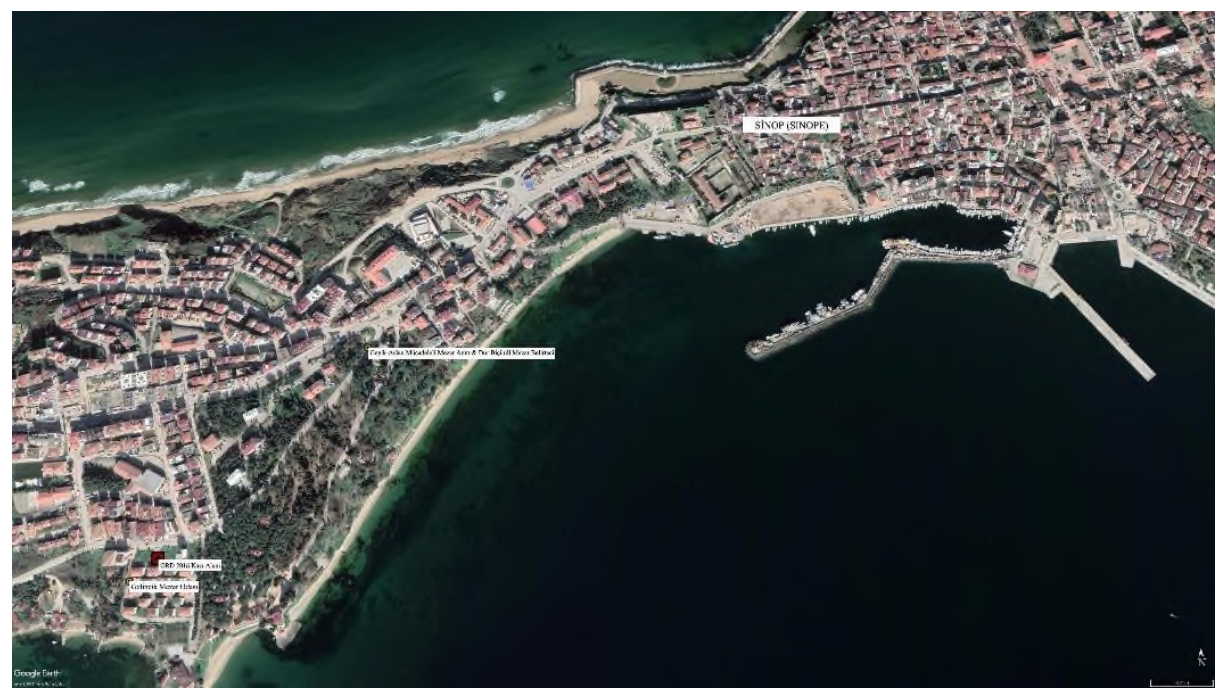




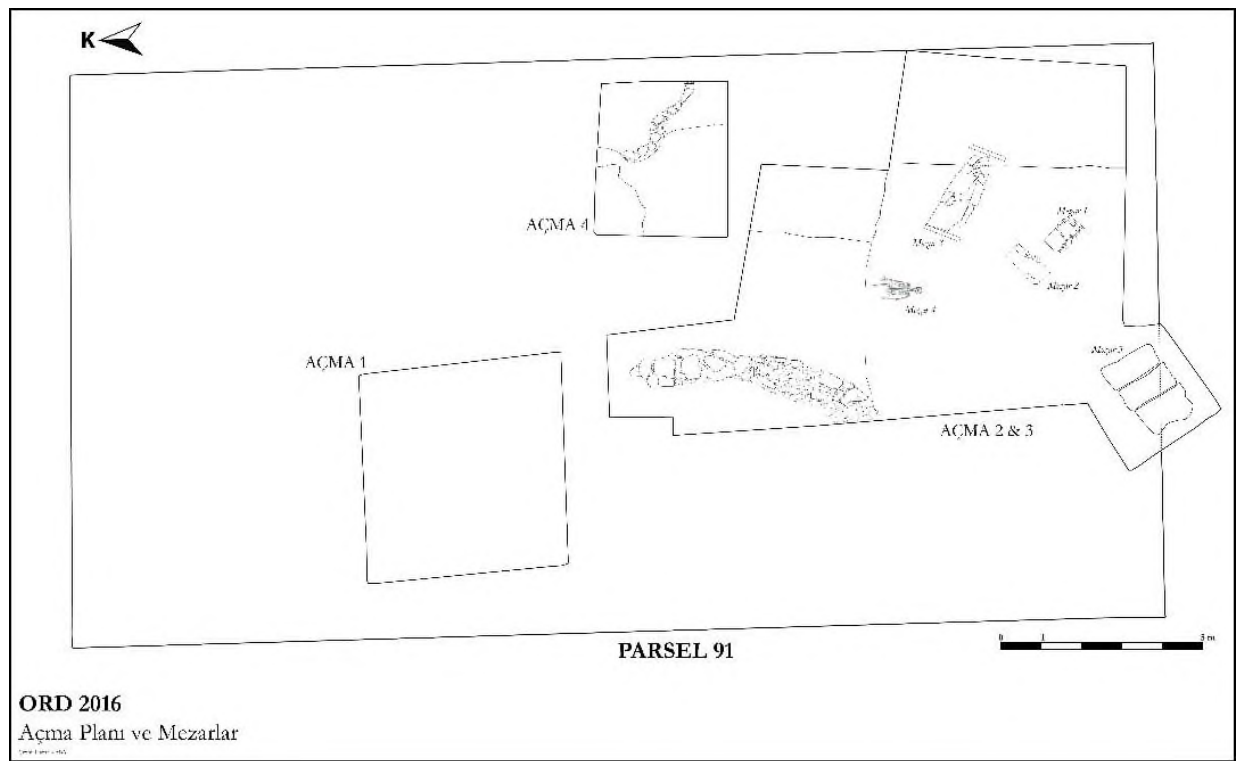

Resim 3

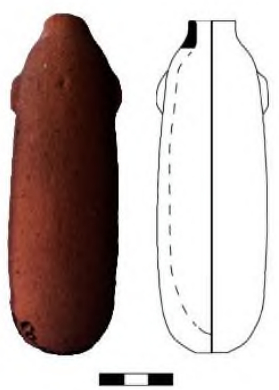

a

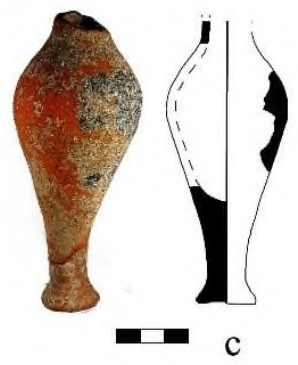

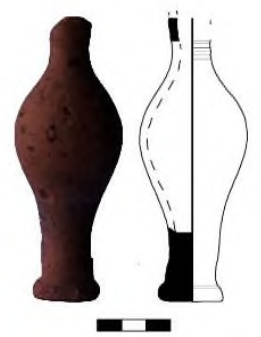

b
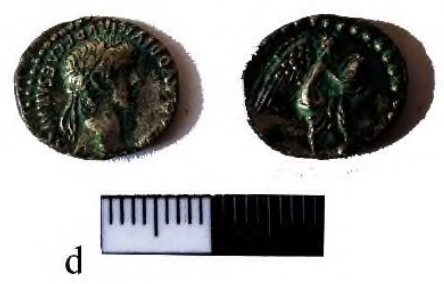

\section{Resim 4}



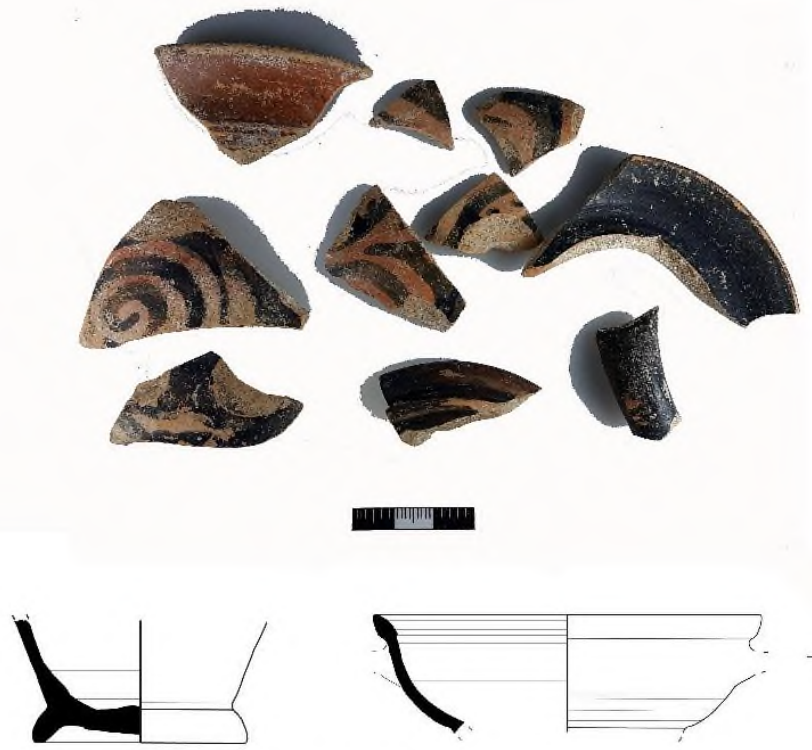

미

$\operatorname{Resim} 5$
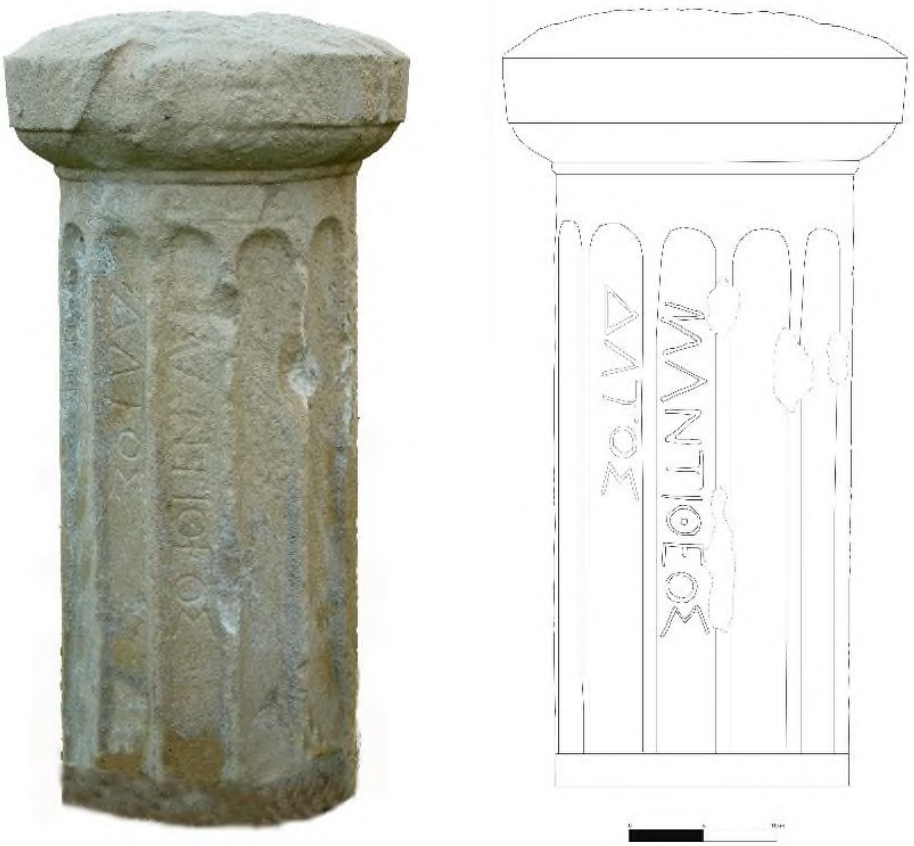

Resim 6 


\section{Eray AKSOY}

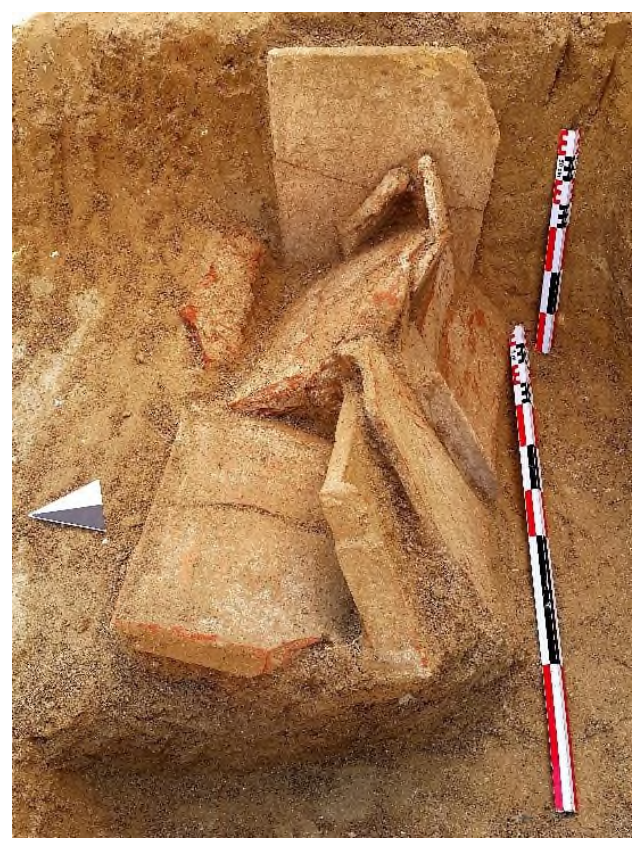

\section{Resim 7}
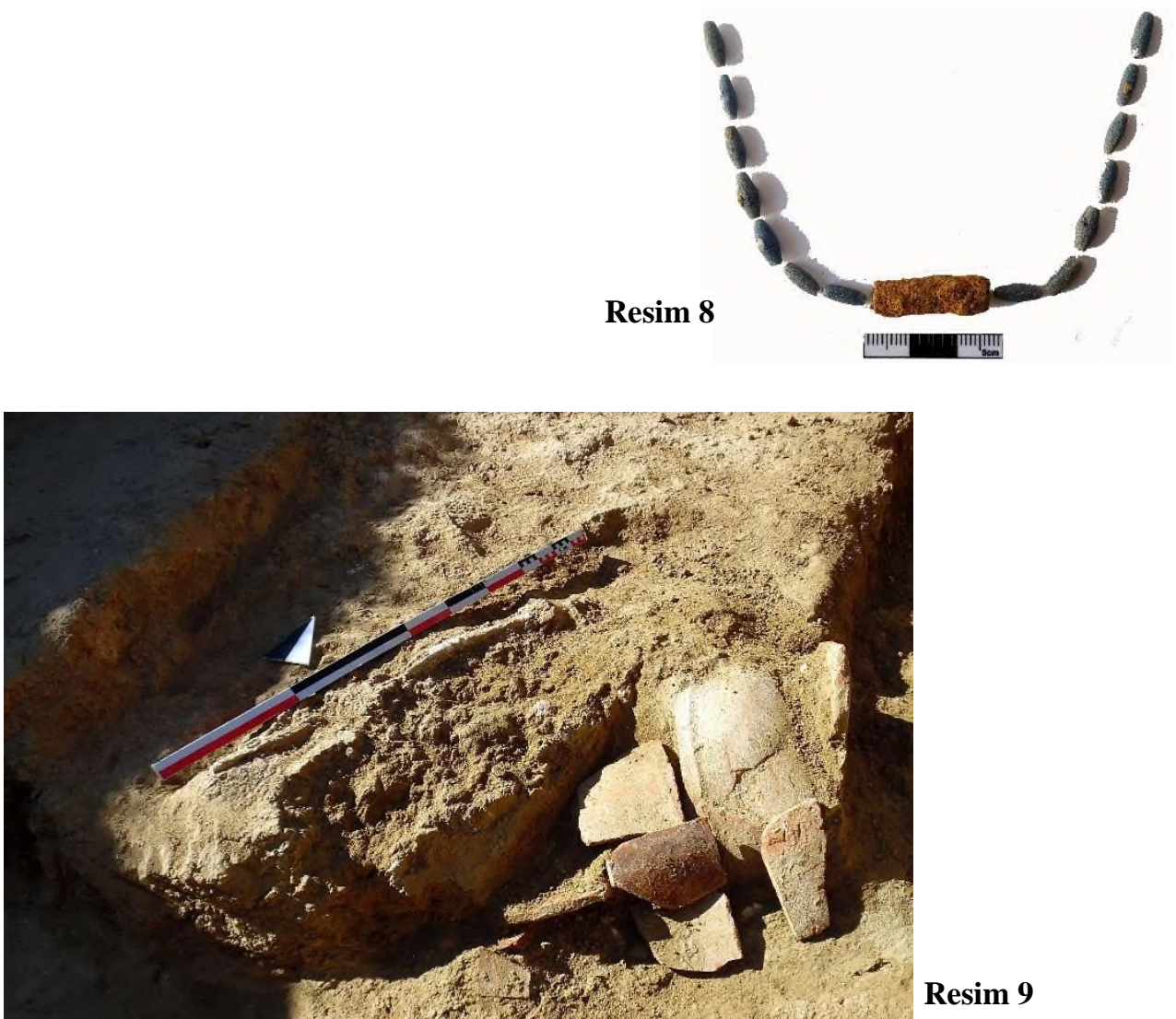
Sinope Batı Nekropolünden Yeni Bir Gömü Alanı - Ord 2016

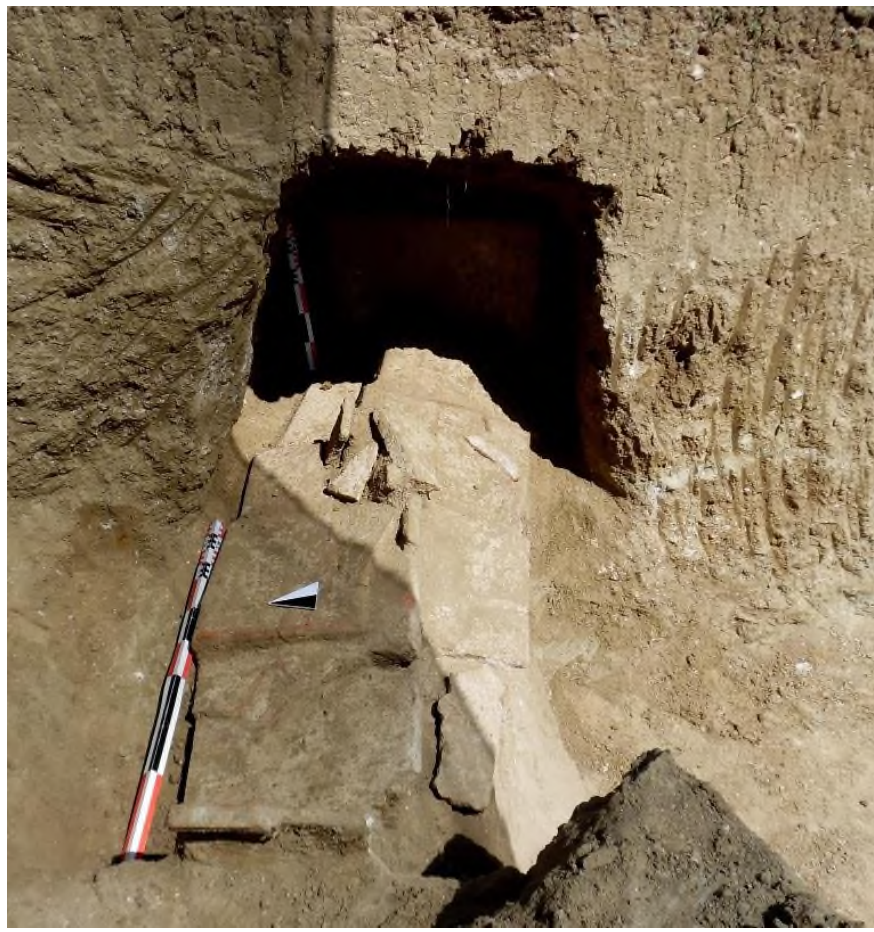

Resim 10
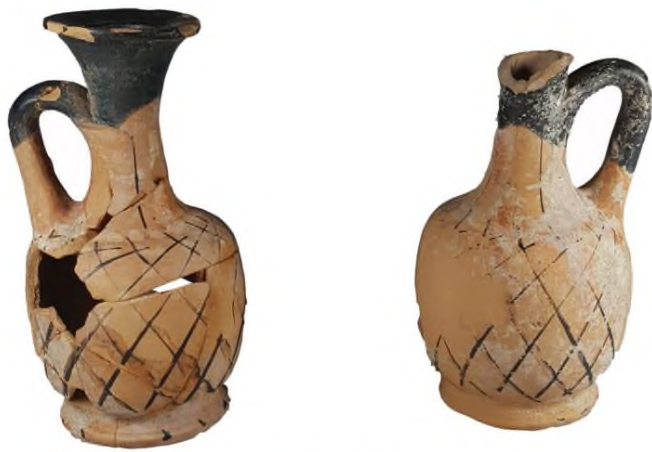

a

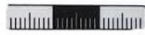

b
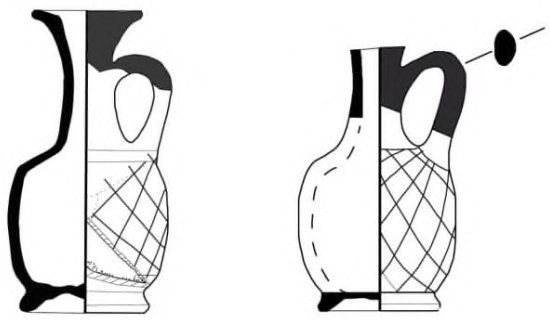

Resim 11 


\section{Eray AKSOY}

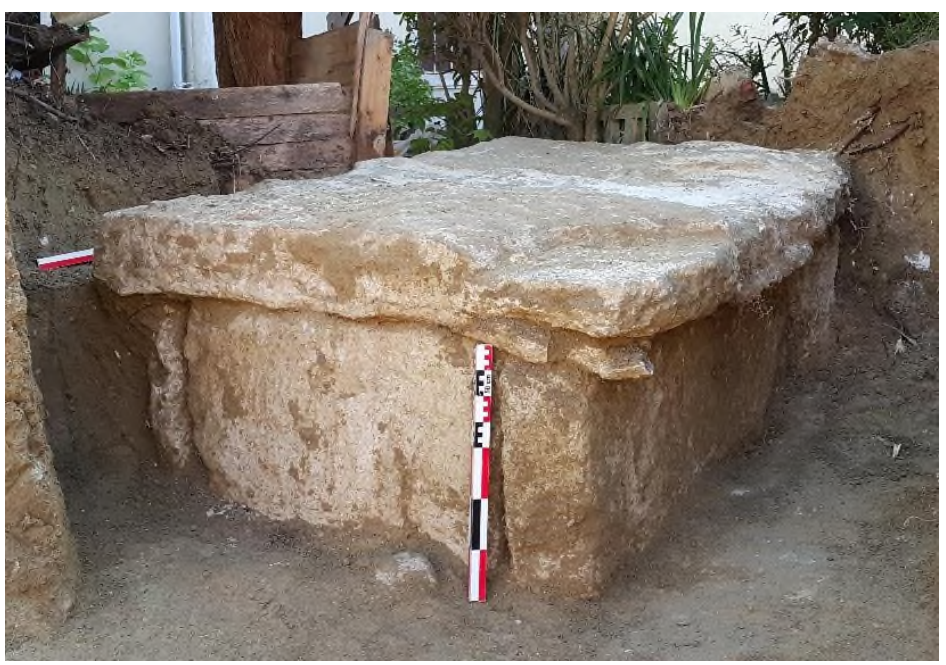

Resim 12

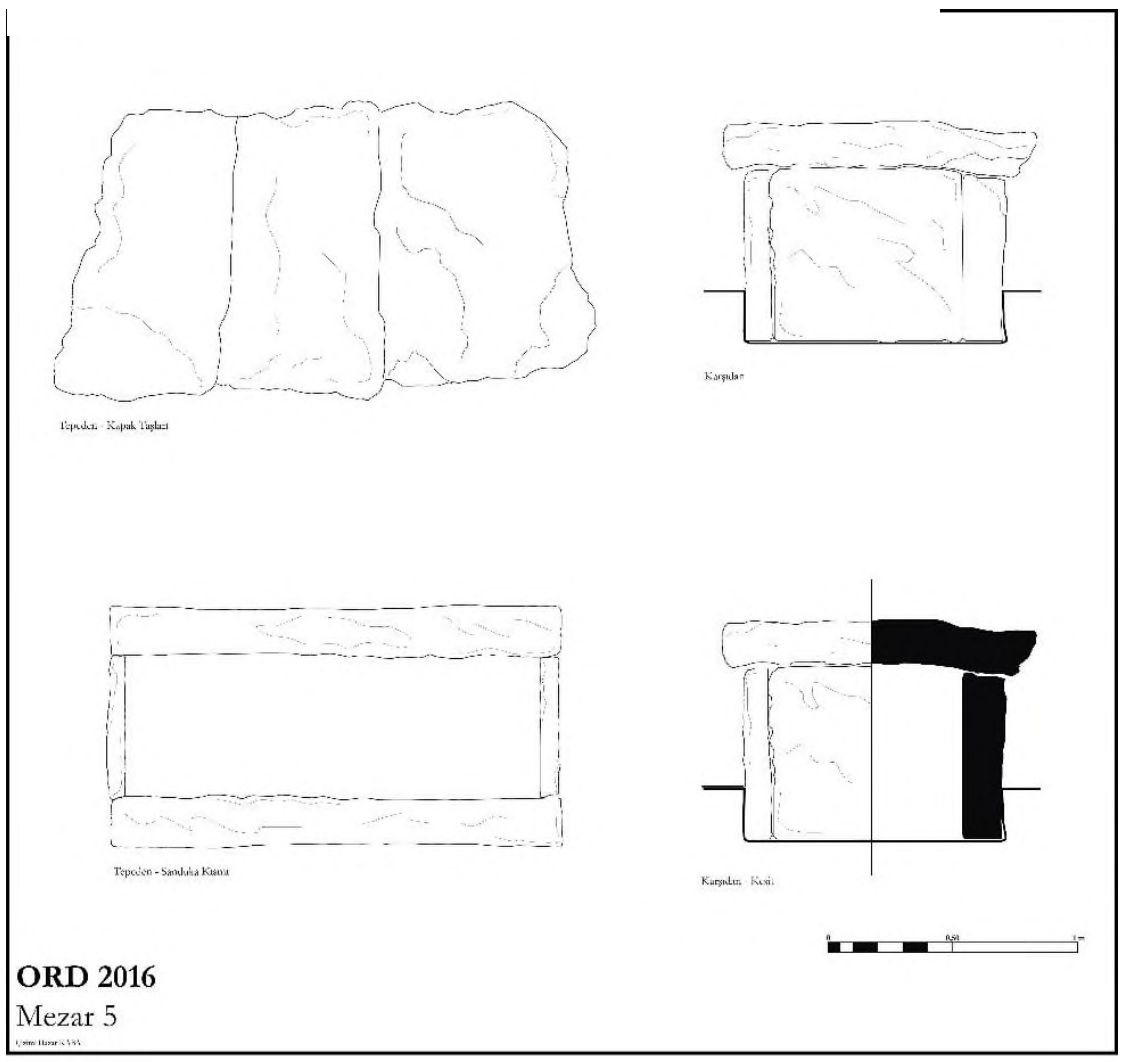

Resim 13 
Sinope Batı Nekropolünden Yeni Bir Gömü Alanı - Ord 2016

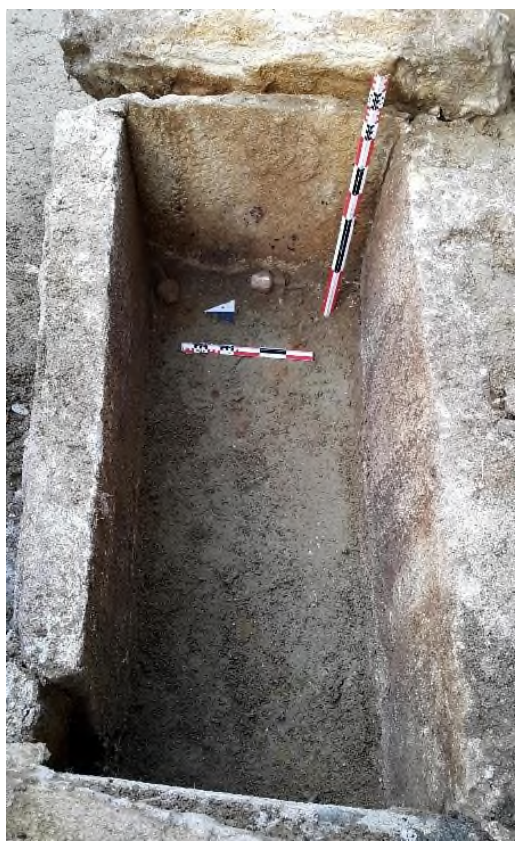

\section{Resim 14}
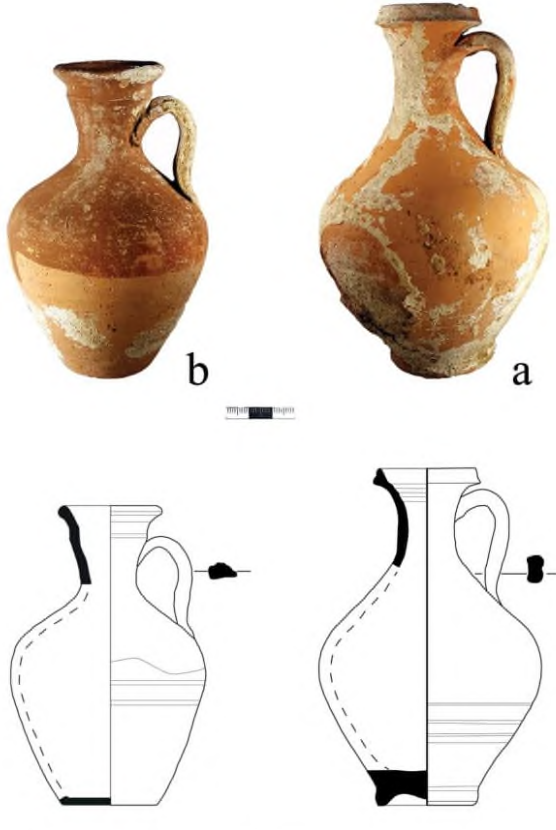

Resim 15

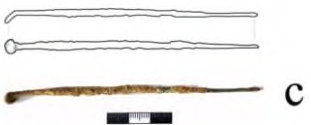

